\title{
Alternative products on Asian soybean rust control and their influence on defoliation, productivity and yield components
}

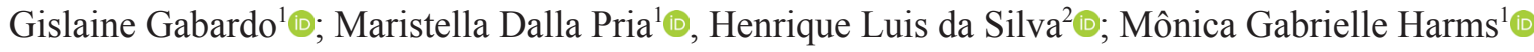

${ }^{1}$ UEPG - Department of Phytotechnology and Plant Protection, Av. Carlos Cavalcanti, 4748, CEP 84030-900, Ponta Grossa-PR, Brazil; ${ }^{2}$ IAPAR

- Technology diffusion - Av. Presidente Kennedy, s/n, KM 496, CEP 84043-540 Ponta Grossa-PR, Brazil.

Corresponding Author: Gislaine Gabardo (gislainegabardo2007@yahoo.com.br).

Data de chegada: 28/11/2019. Aceito para publicação em: 15/03/2020.

$10.1590 / 0100-5405 / 231561$

\section{ABSTRACT}

Gabardo, G.; Pria, M.D.; Silva, H.L.; Harms, M.G. Alternative products on Asian soybean rust control and their influence on defoliation, productivity and yield components. Summa Phytopathologica, v.46, n.2, p.98-104, 2020.

To study the efficiency of Asian soybean rust (Phakopsora pachyrhizi) control and to test the effects of using alternative products and fungicides, two field experiments were conducted during the harvest seasons 2013/2014 and 2014/2015. Treatments for the experiments were: 1- control (water); 2acibenzolar-S-methyl; 3- calcium; 4- micronutrients: copper, manganese and zinc; 5- micronutrients: manganese, zinc and molybdenum; 6- NK fertilizer; 7-Ascophyllum nodosum, and 8- azoxystrobin + cyproconazole. The evaluated variables were: Asian soybean rust severity, defoliation, productivity and yield components. Based on severity data, the area under the disease progress curve was calculated. In the two experiments, the alternative products had no effect on Asian soybean rust or defoliation. Only the treatment with fungicide controlled the disease and decreased defoliation. The yield component affected by the treatments was the number of pods per plant, in both harvest seasons. Treatment with the fungicide protected soybean from yield loss in both experiments. Defoliation was strongly correlated with the weight of one thousand seeds and the number of pods per plant, emphasizing the importance of maintaining the leaf area to ensure the maintenance of the yield components in soybean crop.

Keywords: Glycine max, Phakopsora pachyrhizi, alternative products, micronutrients, disease control.

\section{RESUMO}

Gabardo, G.; Pria, M.D.; Silva, H.L.; Harms, M.G. Produtos alternativos no controle da ferrugem asiática da soja e sua influencia no desfolhamento, produtividade e componentes de rendimento. Summa Phytopathologica, v.46, n.2, p.98-104, 2020.

Para estudar a eficiência do controle da ferrugem asiática da soja (Phakopsora pachyrhizi) e testar os efeitos do uso de produtos alternativos e fungicidas, foram realizados dois experimentos de campo durante as safras 2013/2014 e 2014/2015. Os tratamentos para os experimentos foram: 1- controle (água); 2- acibenzolar-S-metil; 3- cálcio; 4- micronutrientes: cobre, manganês e zinco; 5- micronutrientes: manganês, zinco e molibdênio; 6- fertilizante NK; 7-Ascophyllum nodosun; e 8-azoxistrobina + ciproconazol. As variáveis avaliadas foram: severidade da ferrugem asiática, desfolhamento, produtividade e componentes de rendimento. Com base nos dados de severidade, foi calculada a área abaixo da curva de progresso da doença. Nos dois experimentos, os produtos alternativos não tiveram efeito sobre a ferrugem ou desfolha. Somente o tratamento com fungicida controlou a doença e diminuiu a desfolha. $\mathrm{O}$ componente de rendimento afetado pelos tratamentos foi o número de vagens por planta, nas duas estações. O tratamento com fungicida protegeu a soja da perda de rendimento nos dois experimentos. A desfolha foi fortemente correlacionada com o peso de mil sementes e o número de vagens por planta, enfatizando a importância de manter a área foliar para garantir a manutenção dos componentes de rendimento na cultura da soja.

Palavras-chave: Glycine max, Phakopsora pachyrhizi, produtos alternativos, micronutrientes, controle de doenças.

Soybean, Glycine $\max (\mathrm{L}$.$) Merrill, is an annual legume of$ the family Fabaceae considered one of the main crops in global agriculture. This grain is economically important worldwide due to its productive potential, chemical composition and nutritional value, besides its indispensable use as raw material in several agroindustries (24).

Asian soybean rust (Phakopsora pachyrhizi Syd. \& P. Syd.) is one of the most severe diseases that affect soybean crop, causing losses that vary from $10 \%$ to $90 \%(19,30)$. Considering that Asian soybean rust is highly destructive, a commonly adopted management option is the use of fungicides, since cultivars fully resistant to this disease have not been developed yet (22).
Indiscriminate use of agrochemicals raises the crop production cost and can damage the environment, leading to environmental imbalance and selection of fungal populations resistant to fungicides (22). The society has put pressure on the agricultural system for sustainable food production without residues, including the production of organic soybean (10). This has led researchers to investigate alternatives for disease control, such as resistance inducers, algae extracts and foliar fertilizers.

The present study aimed to evaluate the effects of foliar application of alternative products on Asian soybean rust severity, defoliation, yield components and productivity of soybean plants in a non-tillage system in the harvest seasons 2013/2014 and 2014/2015. 


\section{MATERIAL AND METHODS}

Two experiments with soybean crops were conducted in distinct harvest seasons (2013/2014 and 2014/2015), in the municipality of Ponta Grossa - Paraná State, Brazil, located at $25^{\circ} 13^{\prime}$ latitude, $50^{\circ} 03^{\prime}$ longitude, and $900 \mathrm{~m}$ altitude. The common cultivation system for soybean in that area is the non-tillage system. Data on average monthly temperatures, total monthly rainfall, and average humidity in that area during the experimental period were provided by the agrometeorological station located near the experimental field (data not shown).

The used soybean cultivar was 'BMX Potência RR', and sowing was carried out in a non-tillage system with wheat straw on 12/18/2013 and $12 / 16 / 2014$. Row spacing was $0.45 \mathrm{~m}$, and 15 seeds per meter were used to obtain a final density of 12 plants $\mathrm{m}^{-1}$ and a final population of 250,000 plants ha ${ }^{-1}$. Weed and insect control were carried out when needed.

Experimental design was in completely randomized blocks, with eight treatments and four replicates, in plots measuring $6.0 \times 4.0 \mathrm{~m} \mathrm{(24}$ $\left.\mathrm{m}^{2}\right)$, showing usable area of $5.0 \times 1.8 \mathrm{~m}\left(9.0 \mathrm{~m}^{2}\right)$. Treatments consisted in foliar application of the products: 1 - control (water); 2 - acibenzolarS-methyl (ASM) (Bion $\left.500 \mathrm{WG}{ }^{\circledR}\right)\left(25\right.$ g p.c. ha $\left.{ }^{-1}\right) ; 3$ - calcium (Max Fruit $\left.{ }^{\circledR}\right)\left(0.75\right.$ L p.c. ha $\left.{ }^{-1}\right) ; 4$ - micronutrients: copper, manganese, and zinc (Wert Plus $\left.{ }^{\circledR}\right)$ (0.75 L p.c. ha $\left.{ }^{-1}\right)$; 5 - micronutrients: manganese, zinc, and molybdenum (V6®) (0.75 L p.c. ha $\left.{ }^{-1}\right) ; 6$ - NK fertilizer (Hight Roots $\left.{ }^{\circledR}\right)\left(0.75\right.$ L p.c. ha $\left.^{-1}\right) ; 7$ - Ascophyllum nodosum (Acadian $\left.{ }^{\circledR}\right)(2.0 \mathrm{~L}$ p.c. ha $\left.^{-1}\right)$, and 8 - azoxystrobin + cyproconazole (Priori XTRA $\left.{ }^{\circledR}\right)(300$ $\mathrm{mL}$ p.c. ha $\left.{ }^{-1}\right)$ added of Nimbus adjuvant $(0.5 \% \mathrm{v} / \mathrm{v})$. The development of the soybean crop followed the phenological scale proposed by Fehr \& Caviness (14), reviewed by Ritchie et al. (27).

In both experiments, four applications of each alternative product were performed in the phenological stages V 3 ( $2{ }^{\text {nd }}$ developed trifoliate), V6 ( $5^{\text {th }}$ open trifoliate), R1 (beginning of flowering), and R5.1 (grains perceptible to touch - $10 \%$ grain formation). Two fungicide applications were performed in the phenological stages R1 and R5.1. All treatments were applied with a $\mathrm{CO}_{2}$-pressurized backpack sprayer equipped with a bar containing simultaneous arrangement of four swing jet nozzles (XR 11002 ) spaced $0.50 \mathrm{~m}$ apart, which had constant pressure of $3 \mathrm{~kg} \mathrm{~cm}^{-2}$. Application was carried out under suitable climate conditions: relative humidity higher than $60 \%$ and temperatures below $30^{\circ} \mathrm{C}$.

Asian soybean rust severity was weekly assessed during the crop cycle. The percentage of infected leaf tissue was estimated according to the scale proposed by Godoy et al. (15) for all leaves of 10 plants randomly chosen from the two central rows of each plot. The lower, middle and upper thirds of each plant were evaluated, and the average of the thirds was used to estimate the average value for the whole plant. Based on the severity data, the area under the disease progress curve (AUDPC) was calculated (28). Defoliation was evaluated when the plants of the control plot reached $80-85 \%$ defoliation, which was estimated based on the diagrammatic scale developed by Hirano et al. (18).

The yield components evaluated for plants harvested from onemeter row in each plot were: plants per meter, number of pods per plant, number of grains per pod, and weight of 1000 grains (WTG). At the end of the crop cycle, when grain moisture was around $15 \%$, the plants in the useful area of each plot were manually harvested. The material was weighed and its moisture measured with a universal meter. The obtained values were converted to $13 \%$ moisture to estimate grain productivity.

Data were subjected to analysis of variance according to F-test, and significant averages were compared according to Scott-Knott test at $5 \%$ probability. Analyses were performed with the statistical software SASM-Agri. Pearson correlation coefficients (r) were determined for AUDPC, defoliation and yield components with the software STATISTICA®.

\section{RESULTS AND DISCUSSION}

Phakopsora pachyrhizi can infect soybean crops from early development stages (11). However, in the first experiment (2013/2014), disease symptoms were first observed only during the reproductive stage, at 65 DAE (R5.1), and maximum severity was $46.03 \%$ in stage R5.5 (94 DAE) (Figure 1). In the second experiment (2014/2015), the first symptoms were observed at 53 DAE (R2), and the disease severity was highest $(82.79 \%)$ at 87 DAE. The second experiment had higher disease severity, compared to the first experiment, and earlier symptoms (Figure 1).

The severity of Asian soybean rust was different between the two experiments (Figure 1), which can be explained by the diverse climate conditions. In 2013/2014, Asian soybean rust was first observed in February, probably due to higher precipitation volumes, average temperature of $19.5^{\circ} \mathrm{C}$, high humidity $(87.4 \%)$, and well distributed rain periods. Rainfall during the vegetative phase was $284.3 \mathrm{~mm}$. After 50 DAE, during the reproductive phase, there was rainfall volume of 371.2 $\mathrm{mm}$, well distributed rain periods, mild temperatures and high average humidity, which favored Asian soybean rust epidemic at 65 DAE.

However, in 2014/2015, Asian soybean rust was first observed in January, which may be explained by the higher precipitation volumes recorded, as well as average temperature of $20.7{ }^{\circ} \mathrm{C}$, high humidity (85.4\%), and well distributed rain periods. The rainfall volume during the vegetative phase was $319.4 \mathrm{~mm}$. After 50 DAE, in the reproductive phase, there was rainfall volume of $363.20 \mathrm{~mm}$, well distributed rain periods, mild temperatures and high average humidity.

Studies by Del Ponte et al. (11) showed that rainfall has a direct effect on Asian soybean rust epidemic since it is related to the pathogen dispersion within the canopy of the crop, especially in the early stages of the disease. This effect is related to the impact of water droplets that disperse the urediniospores among leaves (13).

Regarding the AUDPC for the three thirds of the plant (lower, middle and upper) and the whole plant, the only treatment that differed from control in both experiments was the treatment with fungicide (Table 1). The AUDPC values obtained in the second harvest season were higher than those obtained in the first harvest season, and the averages were higher for the lower third of the plant in both seasons.

Only the fungicide treatment differed from control considering both the plant thirds and the whole plant (Table 1). These data confirm the importance of Asian soybean rust control with fungicides, since the alternative products were not efficient and the genetic resistance of the crop is not effective against the disease $(30,16,22)$. In addition, the pathogen has high genetic variability; therefore, geographically distant populations may differ in aggressiveness (21).

Treatment with acibenzolar-S-methyl (ASM) did not differ from control considering the AUDPC (Table 1). These results are in agreement with those obtained by Silva et al. (29) and Carvalho \& Oliveira (5), who stated that ASM had no effect on Asian soybean rust in soybean crops. However, Duarte et al. (12) and Dallagnol et al. (9) obtained protection against Asian soybean rust after applying ASM at higher levels, compared to the level used in the present study, 


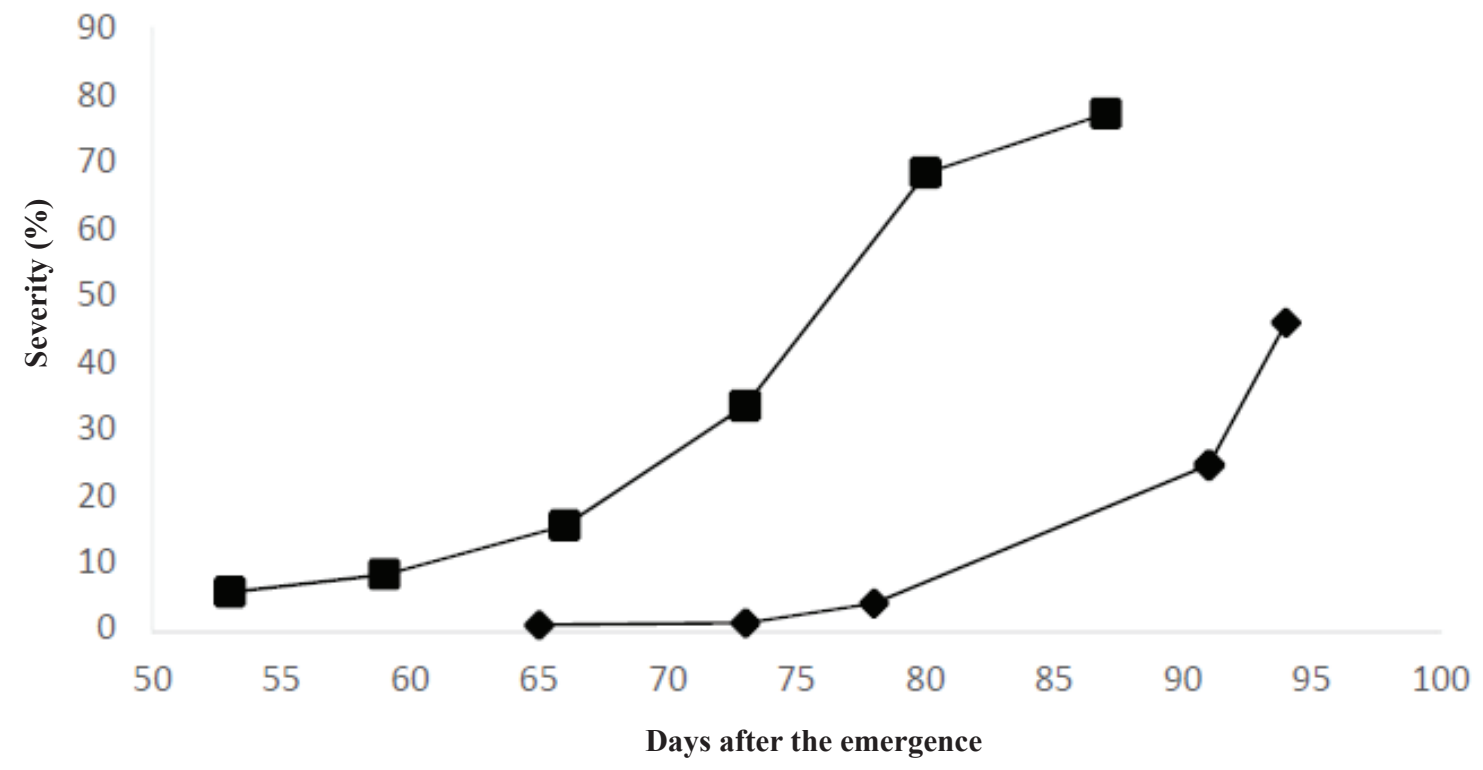

$\longrightarrow$ Harvest 2013/14 - Harvest 2014/15

Figure 1. Severity of Asian soybean rust (Phakopsora pachyrhizi), obtained for the control in the harvest seasons 2013/2014 and 2014/2015, according to the days after emergence of soybean plants (Glycine max). The tested cultivar was 'BMX Potencia RR', Ponta Grossa, Paraná State, Brazil.

which was 25.0 g p.c. ha ${ }^{-1}$, in four sprays, and did not protect the crop against the disease. Similarly, Carvalho \& Oliveira (5) did not succeed in controlling Asian soybean rust with three applications of $25.0 \mathrm{~g}$ p.c. ha ${ }^{-1}$ ASM. Silva et al. (29) used two applications of an ASM level $\left(12.5\right.$ g p.c. ha $\left.{ }^{-1}\right)$ lower than that tested in the present study and failed to control Asian soybean rust.

However, successful experiments using ASM to control Asian soybean rust, such as that of Duarte et al. (12), recorded protection with three applications of the highest level (125 g p.c. ha $\left.{ }^{-1}\right)$. According to Dallagnol et al. (9), ASM was efficient in protecting against Asian soybean rust with three sprays of 50 g p.c. ha ${ }^{-1}$. The same authors obtained the best results when ASM was sprayed before the symptoms of the disease could be observed. In the present study, although there was no difference between inducers, all sprays were preventively performed.

Based on the results of the above-mentioned studies and on the present experiment, a level equal to or lower than 25.0 g p.c. ha ${ }^{-1}$ will probably not be effective in protecting against Asian soybean rust. Experiments with a level equal to or greater than 50 g p.c. ha ${ }^{-1}$ were efficient, although the inducer (ASM) was recommended to be applied at 25.0 g p.c. ha-1 (1).

The AUDPC values were higher for the middle and lower thirds of the plants (Table 1). According to Igarashi et al. (20), this is due to the thickening of the crop structure, which makes it difficult for sprays to penetrate the canopy, mainly in the middle and lower thirds. Thickening of crops also provides a favorable microclimate for the disease development, including milder temperatures and higher humidity.

As regards defoliation, only the treatment with fungicide application differed from the other treatments (Table 2), showing 37.75\% and $36.30 \%$ defoliation, compared to $84.75 \%$ and $85.30 \%$ defoliation found for the control treatment in the first and second harvest seasons, respectively. Infection with $P$. pachyrhizi causes rapid yellowing and early leaf dropping, resulting in premature defoliation in the crop, as previously observed by Henning et al. (17).

Defoliation in the fungicide treatment (azoxystrobin + cyproconazole) differed from that in the remaining treatments (Table 2). Miles et al. (23) also obtained lower levels of severity and defoliation caused by Asian soybean rust when triazoles and strobilurins were applied simultaneously, compared to the control treatment and the separate use of triazoles. This confirms that combining two or more active ingredients showing distinct mechanisms of action provides more efficient control of Asian soybean rust. In addition, these combinations allow the product to increase its spectrum of action in the field, guaranteeing a greater residual effect and reducing the risk of emergence of pathogen populations resistant to the fungicide.

Dallagnol et al. (9) verified that ASM application led to greater defoliation, compared to co-application of ASM activator and the fungicide (pyraclostrobin + epoxiconazole). This evidences that coapplying activators with fungicides is needed to reduce defoliation caused by Asian soybean rust.

Excessive defoliation may affect soybean grain productivity, which depends on the photosynthesis (4). Early defoliation in the crop reduces productivity by interfering in physiological processes, which results in a lower number of seeds per pod and a lower WTG.

Among the evaluated yield components, the number of normal pods per plant differed between treatments in both harvest seasons (Table 3 ). The fungicide treatment had the greatest values and significantly differed from control. There were no statistical differences between treatments and control for the other yield components.

The normal pod component per plant influences productivity and is affected by Asian soybean rust (3), which compromises the photosynthetic area of the plant, causing premature dropping of leaves 
Table 1. Area under the disease progress curve (AUDPC) of Asian soybean rust (Phakopsora pachyrhizi) in the lower, middle and upper thirds of soybean plants (Glycine max), and average values for the whole plant after treatments. The tested cultivar was 'BMX Potência RR', and the two harvests occurred in 2013/2014 and 2014/2015 in Ponta Grossa, Paraná State, Brazil.

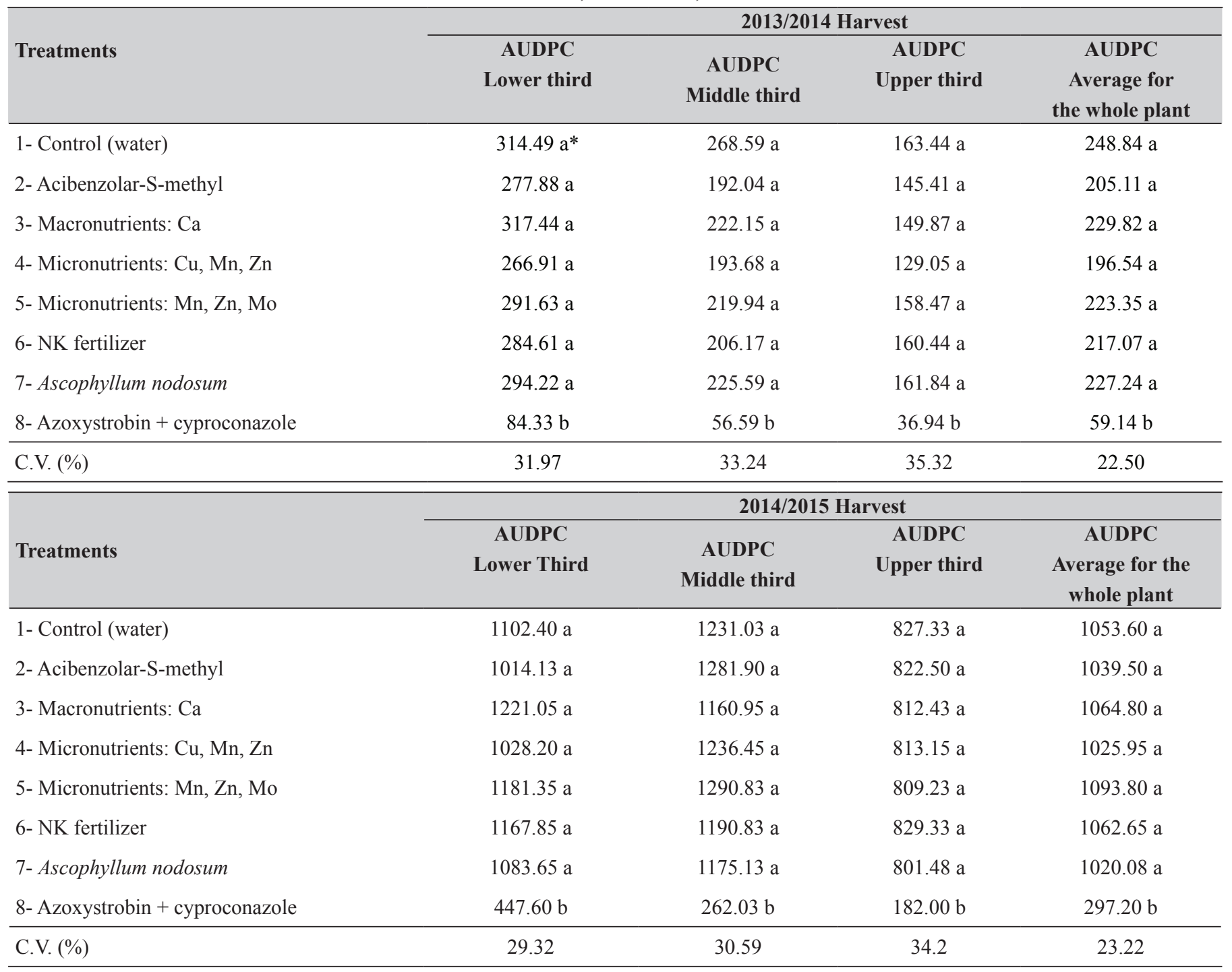

* Means followed by the same lowercase letter in the column do not differ according to Scott-Knott's test at 5\% significance; C.V. = coefficient of variation.

Table 2. Defoliation (\%) as a function of the treatments applied to soybean plants (Glycine max). The tested cultivar was 'BMX Potência RR', and the two harvests occurred in 2013/2014 and 2014/2015 in Ponta Grossa, Paraná State, Brazil.

\begin{tabular}{lcc}
\hline Treatments & Defoliation (\%) 2013/2014 & Defoliation (\%) 2014/2015 \\
\hline 1- Control (water) & $84.75 \mathrm{a}^{*}$ & $85.30 \mathrm{a}^{*}$ \\
2- Acibenzolar-S-methyl & $83.75 \mathrm{a}$ & $86.50 \mathrm{a}$ \\
3- Macronutrients: Ca & $85.25 \mathrm{a}$ & $86.00 \mathrm{a}$ \\
4- Micronutrients: Cu, Mn, Zn & $74.25 \mathrm{a}$ & $82.30 \mathrm{a}$ \\
5- Micronutrients: Mn, Zn, Mo & $85.25 \mathrm{a}$ & $83.80 \mathrm{a}$ \\
6- NK fertilizer & $83.50 \mathrm{a}$ & $87.30 \mathrm{a}$ \\
7- Ascophyllum nodosum & $83.00 \mathrm{a}$ & $36.30 \mathrm{a}$ \\
8- Azoxystrobin + cyproconazole & $37.75 \mathrm{~b}$ & 6.68 \\
\hline C.V. $(\%)$ & 9.33 & 6 \\
\hline
\end{tabular}

*Means followed by the same lowercase letter in the column do not differ according to Scott-Knott's test at 5\% significance; C.V. = coefficient of variation. 
Table 3. Yield component, number of normal pods per plant and productivity $\left(\mathrm{kg} \mathrm{ha}^{-1}\right)$ as a function of treatments applied to soybean plants $(G l y c i n e$ max). The tested cultivar was 'BMX Potência RR', and the two harvests occurred in 2013/2014 and 2014/2015 in Ponta Grossa, Paraná State, Brazil.

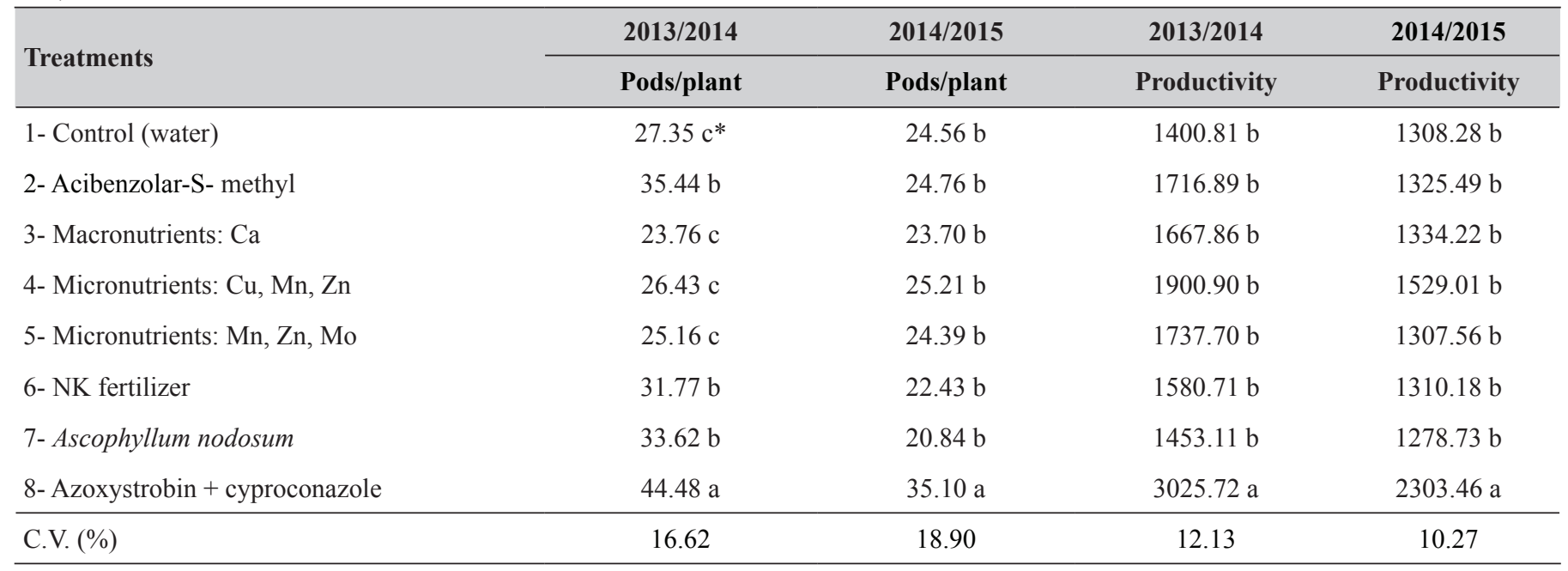

* Means followed by the same lowercase letter in the column do not differ according to Scott-Knott's test at $5 \%$ significance; C.V. $=$ coefficient of variation

and consequently preventing the full development of pods and grains (17). Another aspect reported by Barros et al. (3) is that Asian soybean rust can cause abortion and pod drop when affecting crops in pod formation stage. This may explain the difference in the number of pods per plant found in the present experiment.

Treatments with ASM, NK fertilizer and A. nodosum showed higher numbers of pods per plant in the first harvest, compared to control; however, there was no effect on plant productivity (Table 3). According to Peixoto et al. (25), this characteristic is not sufficient to ensure that the productivity potential was reached, since it depends on the plant's capability of forming grains.

There were no differences in yield between the control treatment and the alternative treatments (Table 3). However, the yield found for the fungicide treatment differed from that obtained for all other treatments. In the harvest season 2013/2014, the average yield of the control treatment was $1,400.81 \mathrm{~kg} \mathrm{ha}^{-1}$, while maximum productivity reached $1,900.90 \mathrm{~kg} \mathrm{ha}^{-1}$ in the presence of the alternative products and $3,025.72 \mathrm{~kg} \mathrm{ha}^{-1}$ in the presence of the fungicide. There was an increase of $116.00 \%$ in yield when the fungicide was applied (Table 3 ). The yield obtained in the presence of fungicide was close to the average yield obtained in the state of Paraná, which was 2,950.00 kg $\mathrm{ha}^{-1}$ in the harvest season 2013/2014 (6).

In the harvest season 2014/2015, the average yield of the control treatment was $1,308.28 \mathrm{~kg} \mathrm{ha}^{-1}$, while maximum productivity was $1,529.01 \mathrm{~kg} \mathrm{ha}^{-1}$ in the presence of the alternative products and 2,303.46 $\mathrm{kg} \mathrm{ha}^{-1}$ in the presence of the fungicide. There was an increase of $76.07 \%$ in productivity when the fungicide was applied (Table 3 ). The yield obtained with the fungicide was lower than the average productivity in the state of Paraná from the harvest season 2014/2015, which was $3,043.00 \mathrm{~kg} \mathrm{ha}^{-1}(7)$.

Carvalho \& Oliveira (5) obtained a similar result since 3 applications of ASM treatment led to productivity of $1,160.90 \mathrm{~kg} \mathrm{ha}^{-1}$, not differing from control $\left(1,195.90 \mathrm{~kg} \mathrm{ha}^{-1}\right)$, but the treatment with fungicide (azoxystrobin + cyproconazole) presented higher productivity $\left(2,142.2 \mathrm{~kg} \mathrm{ha}^{-1}\right)$.

Productivity of the second harvest was lower than that of the first one (Table 3). This can be explained by the earlier occurrence of Asian soybean rust (65 DAE in the first harvest and $53 \mathrm{DAE}$ in the second harvest) and the greater disease severity in the second harvest (Figure 1). Only the fungicide treatment controlled the disease, confirming that Asian soybean rust control results in less defoliation and higher productivity (Tables 1, 2, 3 and 4).

Silva et al. (29) reported that soybean treated with ASM associated with fungicide (pyraclostrobin + epoxiconazole) had increased productivity. However, in the present study, application of ASM alone did not lead to differences in total productivity (Table 3). Carvalho $\&$ Oliveira (5) confirmed that only fungicide treatments prevented productivity loss.

Dallagnol et al. (9) tested three soybean cultivars (IAS 5, CD 201 and RS 10) applied with ASM and observed that the cultivars IAS 5 and RS 10 showed no difference in productivity. However, the cultivar CD 201 had a significant increase of $9.2 \%$ in productivity. This finding indicates different responses by cultivars, which may explain the absence of response to ASM application by the cultivar tested in the present study.

According to Datnoff \& Rodrigues (8), mineral nutrients are responsible for valuable functions in the plant metabolism, not only influencing growth and productivity but also increasing the resistance to pathogens. A large number of nutrients are enzyme cofactors, activators, inhibitors or modulators of various metabolic processes in the plant and can participate in the synthesis of compounds used in physical and/or chemical barriers. Thus, mineral nutrition largely determines the resistance or susceptibility of a plant to various diseases. In this study, there was no significant difference in productivity when micro and macronutrients, or the extract of the alga $A$. nodosum, were used.

To better understand the factors that interfered in the productivity recorded during the experiments, they were correlated with yield components, Asian soybean rust and defoliation (Table 4). Among yield components, in the first experiment, the greatest correlation with productivity was found for WTG $(r=0.79)$ and normal pods per plant $(r=0.46)$. In the second harvest, the component with the highest correlation was the number of pods per plant $(r=0.96)$, followed by WTG $(r=0.84)$.

According to the results of correlation analysis (Table 4), Asian soybean rust negatively correlated with productivity. In the second harvest, the negative correlation was stronger; thus, Asian soybean rust 
Table 4. Pearson correlation coefficient between characteristics of the two harvests: productivity, yield components, area under the disease progress curve (AUDPC) of Asian soybean rust (Phakopsora pachyrhizi) and defoliation in soybean plants (Glycine max). The tested cultivar was 'BMX Potência RR', and the two harvests occurred in 2013/2014 and 2014/2015 in Ponta Grossa, Paraná State, Brazil.

\begin{tabular}{|c|c|c|c|}
\hline & & \multicolumn{2}{|c|}{ Productivity } \\
\hline \multirow{4}{*}{ Yield components } & Plant $\mathrm{m}^{2}$ & 0.26 & -0.21 \\
\hline & Normal pod per plant & 0.46 & 0.96 \\
\hline & Aborted pod per plant & -0.21 & -0.66 \\
\hline & Weight of a thousand grains & 0.79 & 0.84 \\
\hline Disease & AUDPC of Asian soybean rust & -0.60 & -0.97 \\
\hline Defoliation & & -0.81 & -0.98 \\
\hline
\end{tabular}

had a greater effect on reducing productivity. Defoliation, compared to productivity, exhibited a strong negative correlation in both harvests. Therefore, the higher the defoliation, the lower the productivity. In addition, the higher the WTG and the number of pods per plant, the higher the productivity. This emphasizes that the leaf area should be protected to maximize the yield components.

The first harvest produced plants with the same number of grains per pod; however, increased defoliation interfered in grain formation, resulting in lower grain weight and reduced productivity. This can be explained by the occurrence of Asian soybean rust at 65 DAE (R5.1) (Figure 1). According to Peluzio et al. (26), defoliation between stages R5 and R6 leads to lower grain formation.

Barros et al. (2) also observed that defoliation in stages R5 and R6 led to lower grain yield, which was caused by a decrease in WTG. These results corroborate those of the present study, since defoliation in the first harvest was identified in stage R5. This also emphasizes the importance of protecting the leaf area to maintain the yield components.

In the second harvest season, Asian soybean rust was more intense and early, occurring at 53 DAE (R2) (Figure 1). Peluzio et al. (26) stated that defoliation in the stage R4 causes pod abortion when the plant exhibits peaks of photosynthetic activity for pod and grain formation. Defoliation was identified in R4 in the second harvest, which explains the lower number of pods per plant obtained for the treatments without disease control.

Further experiments are needed on the combination of alternative products with fungicides applied to soybean plants, which may contribute to more satisfactory results. In addition, combination of products may reduce the risk of fungicide-resistant isolates.

In both harvests, the tested alternative products had no effect on Asian soybean rust or defoliation.

The fungicide (azoxystrobin + cyproconazole) was the only treatment that controlled Asian soybean rust and reduced defoliation in both harvests.

In both harvests, the number of pods per plant and productivity were positively influenced by the application of the fungicide (azoxystrobin + cyproconazole).

Correlation analysis evidenced the importance of Asian soybean rust control for the maintenance of leaf area and yield components in soybean crop.

\section{REFERENCES}

1. Agência de defesa agropecuária do Paraná. Fungicidas. Curitiba: Adapar, 2016. Available at: www.adapar.pr.gov.br/arquivos/File/defis/DFI/Bulas/ Fungicidas/priorixtradez2016.pdf. Accessed on: October 10, 2016.

2. Barros, H.B.; Santos, M.M.; Pelúzio, J.M.; Rocha, R.N.C.; Silva, R.R.; Vendrusco, J.B. Desfolha na produção de soja (Glycine max 'M-SOY'), cultivada no cerrado, em Gurupi-TO, Brasil. Bioscience Journal, Uberlândia, v.18, p. 5-10, 2002.

3. Barros, H.B.; Sediyama, T.; Reis, M.S.; Cecon, P.R. Efeito do número de aplicações de fungicidas no controle da ferrugem asiática da soja. Acta Scientiarum: Agronomy, Maringá, v.30, p.239-245, 2008.

4. Board, J.E.; Kumudini, S.; Omielan, J.; Prior, E.; Kahlon, C.S. Yield response of soybean to partial and total defoliation during the seedfilling period. Crop Science, Madison, v.50, p.703-712, 2010.

5. Carvalho, B.O.; Oliveira, J.A. Action of defense activator and foliar fungicide on the control of Asiatic rust and on yield and quality of soybean seeds. Journal of Seed Science, Londrina, v.35, p.198-206, 2013.

6. CONAB. Companhia nacional de abastecimento, Acompanhamento da safra brasileira de grãos, 2014. Available at: www.conab.gov.br/OlalaCMS/ uploads/arquivos/14_09_10_14_35_09_boletim_graos_setembro_2014. pdf. Accessed on September 16, 2014.

7. CONAB. Companhia nacional de abastecimento, Acompanhamento da safra brasileira de grãos, 2016. Available at: www.conab.gov.br/OlalaCMS/uploads/arquivos/16_06_09_16_49_15_boletim_graos_junho_2016_-_final. pdf. Accessed on August 10, 2016.

8. Datnoff, L.E.; Rodrigues, F.A.; Seebold, K.W. Silicon and plant nutrition. In: Datnoff, L.E.; Elmer, W.H.; Huber, D.M. (ed.). Mineral nutrition and plant disease. Saint Paul, 2007. p.233-246.

9. Dallagnol, L.E.; Navarini, L.; Ugalde, M.G.; Balardin, R.S.; Catelam, R. Use of Acibenzolar-S-Methyl to control foliar diseases of soybean. Summa Phytopathologica, Botucatu, v.32, p.255-259, 2006.

10. Deliopoulos, T.; Kettlewell, P.S.; Hare, M.C. Fungal disease suppression by inorganic salts: a review. Crop Protection, London, v.29, p.1059-1075, 2010.

11. Del Ponte, E.M.; Godoy, C.V.; Li X, Yang, X.B. Predicting severity of Asian soybean rust with empirical rainfall models. Phytopathology, Saint Paul, v.96, p.797-803, 2006.

12. Duarte, H.S.S.; Zambolim, L.; Rodrigues, F.A.; Rios, J.A.; Lopes, U.P. Silicato de potássio, acibenzolar-S-metil e fungicidas no controle da ferrugem da soja. Ciência Rural, Santa Maria, v.39, p.271-277, 2009.

13. Dufault, N.S.; Isard, S.A.; Marois, J.J.; Wright, D.L. Removal of wet deposited Phakopsora pachyrhizi urediniospores from soybean leaves by subsequent rainfall. Plant Disease, Saint Paul, v.94, p.1336-1340, 2010.

14. Fehr, W.R.; Caviness, C.E. Stages of soybean development. Ames: Iowa State University/Cooperative Extension Service, 1997. (Special Report, 80).

15. Godoy, C.V.; Koga, L.J.; Canteri, M.G. Diagrammatic scale for assessment of soybean rust severity. Fitopatologia Brasileira, Brasília, v.31, n.1, p.63-68, 2006. 
16. Godoy, C.V.; Flausino, A.M.; Santos, L.C.M.; Ponte, M.D.P. Eficiência do controle da ferrugem asiática da soja em função do momento de aplicação sob condições de epidemia em Londrina, PR. Tropical Plant Pathology, Brasília, v.34, n.1, p.56-61, 2009.

17. Henning, A.A.; Almeida, A.M.; Godoy, C.V.; Seixas, C.D.S.; Yorinori, J.T.; Costamilan, L.M.; Ferreira, L.P.; Meyer, M.C.; Soares, R.M.; Dias, W.P. Manual de identificação de doenças de soja. 5.ed. Londrina: Embrapa Soja, 2014.

18. Hirano, M.; Hikishima, M.; Silva, A.J.; Xavier, A.S.; Canteri, M.G. Validação de escala diagramática para estimativa de desfolha provocada pela ferrugem asiática em soja. Summa Phytopathologica, Botucatu, v.36, n.3, p.248-250, 2010.

19. Hikishima, M.; Canteri, M.G.; Godoy, C.V.; Koga, L.J.; Silva, A.J.D. Quantificação de danos e relações entre severidade, medidas de refletância e produtividade no patossistema ferrugem asiática da soja. Tropical Plant Pathology, Brasília, v.35, n.2, p.96-103, 2010.

20. Igarashi, W.T.; Aguiar e Silva, M.A.; Igarashi, S.; Abi Saab, O.J.G.; França, J. A Duração e porcentagem de molhamento foliar determinados pelo espaçamento entrelinhas, e influência sobre a ferrugem asiática da soja. Summa Phytopathologica, Botucatu, v.40, n.2, p.123-127, 2014

21. Jorge, V.R.; Silva, M.R.; Guillin, E.A.; Freire, M.C.; Schuster, I.; Almeida, A.M.; Oliveira, L.O. The origin and genetic diversity of the causal agent of Asian soybean rust, Phakopsora pachyrhizi, in South America. Plant Pathology, Oxford, v.64, n.2, p.729-737, 2015.

22. Klosowski, A.C.; May De Mio, L.L.; Miessner, S.; Rodrigues, R.; Stammler, G. Detection of the F129L mutation in the cytochrome b gene in Phakopsora pachyrhizi. Pest Management Science, New York, v.72, n.6, p.1211-1215, 2016.
23. Miles, M.R.; Levy, C.; Morel, W.; Mueller, T.A.; Steinlage, T.; van Rij, N.C. International fungicide efficacy trials for the management of soybean rust. Plant Disease, Saint Paul, v.91, p.1450-1455, 2007.

24. Oliveira, G.D.; Schneider, M. The politics of flexing soybeans: China, Brazil and global agroindustrial restructuring. The Journal of Peasant Studies, London, v.43, p.167-94, 2016.

25. Peixoto, C.P.; Câmara, G.M.S.; Martins, M.C.; Marchiori, L.F.S. Efeito de épocas de semeadura e densidades de plantas sobre o rendimento de cultivares de soja no estado de São Paulo. Revista de Agricultura, Piracicaba, v.77, n.2, p.265-293, 2002.

26. Peluzio, J.M.; Barros, H.B.; Rocha, R.N.C.; Silva, R.R.; Nascimento, I.R. Influência do desfolhamento artificial no rendimento de grãos e componentes de produção da soja [Glycine max (L.) Merrill]. Ciência e Agrotecnologia, Lavras, v.6, n.26, p.1197-1203, 2002.

27. Ritchie, S.W.; Hanway, J.J.; Thompson, H.E.; Benson, G.O. How a soybean plant develops. Ames, Iowa State University of Science and Technology, 1997. 20p. (Special Report, 53).

28. Shaner, G.; Finney, R.E. The effect of nitrogen fertilization on the expression of slow-mildewing resistance in Knox wheat. Phytopathology, Saint Paul, v.67 p.1051-1056, 1977.

29. Silva, O.C.; Santos, H.A.A.; Deschamps, C.; Dalla Pria, M.; May-de-Mio, L.L. Fontes de fosfito e acibenzolar-S-metílico associados a fungicidas para o controle de doenças foliares na cultura da soja. Tropical Plant Pathology, Brasilia, v.38, p.72-77, 2013.

30. Yorinori, J.T.; Paiva, W.M.; Frederick, R.D.; Costamilan, L.M.; Bertagnolli, P.F.; Hartman, G.E.; Godoy, C.V.; Nunes, Jr. J. Epidemics of soybean rust (Phakopsora pachyrhizi) in Brazil and Paraguay (from 2001 to 2003). Plant Disease, Saint Paul, v.89, p.675-677, 2005 